Original Research

\title{
Physiological Responses of Scirpus validus to Nitrate Stress
}

\author{
Kun Li ${ }^{1}$, Hui Li ${ }^{2}$, Ge Shi ${ }^{1}$, Mao Xiao ${ }^{1}$, Chuanrong Li ${ }^{1 *}$, Huicheng Xie \\ ${ }^{1}$ Taishan Forest Ecosystem Research Station/Shandong Provincial Key Laboratory of Soil Erosion \\ and Ecological Restoration, Tai'an, Shandong, China \\ ${ }^{2}$ College of Agriculture and Forestry Science, Linyi University, Linyi, Shandong, China
}

Received: 10 July 2018

Accepted: 21 November 2018

\begin{abstract}
Physiological responses of Scirpus validus to nitrate stress were investigated. The experiment was conducted in an artificial greenhouse over a period of 35 days. The inhibitory effects of nitrate stress on $S$. validus growth were greater at concentrations higher than $10 \mathrm{mmol} \cdot \mathrm{L}^{-1}$. Greater than $10 \mathrm{mmol} \cdot \mathrm{L}^{-1}$ nitrate inhibited the growth of $S$. validus; specifically, the fresh weight, new stem height, $\Delta$ root length, surface area, and root average diameter and volume were reduced. The level of ammonium in the plants was constant, whereas total nitrogen and nitrate nitrogen levels were reduced. Under stress, nitrate damaged the photosynthetic system and strongly reduced the net photosynthetic rate, transpiration rate, quantum yield at $L C P, L S P$, and $P_{\text {nmax }}$. Furthermore, nitrate increased stomatal limitation and conductance and influenced spectral parameters, e.g., reduced both PRI and SDr/SDb. The inhibitory effect of nitrate was most pronounced at $20 \mathrm{mmol} \cdot \mathrm{L}^{-1}$, primarily due to penetration and non-stomatal limitation. This study identified the physiological responses of $S$. validus to nitrate stress. The observed changes in physiological indices for $S$. validus, including photosynthetic parameters and spectral indicators, suggest that nitrate can inhibit root growth, differentiation and photosynthesis in plants, leading to an overall reduction in growth.
\end{abstract}

Keywords: Nitrate, Scirpus validus, Spectra, Photosynthesis, Root

\section{Introduction}

Eutrophication is a phenomenon of excess nutrition that results from the natural or artificial enrichment of inorganic nutrients such that the system cannot regulate the circulation of nutrients [1]. Among 118 lakes in China, the proportion of mesotrophic lakes was $21.4 \%$

*e-mail: chrli@sdau.edu.cn or chrlisd@126.com and that of eutrophication was $78.6 \%$ in 2016 [2]. It is clear that China faces serious water eutrophication, which will affect the ecological landscape and the safety of livestock drinking water [3]. Many factors lead to eutrophication and predominantly involve the addition of nitrogen and phosphorus [4]. In particular, nitrogen is an important cause of eutrophication [5], especially ammonium nitrogen and nitrate nitrogen contents. Large amounts of nitrate-enriched water pose a serious threat to human life and production. The World Health Organization [6] found that drinking high-nitrate water can endanger human health and safety [7]. As a result, 
WHO recommends that the nitrogen content of drinking water be less than $10 \mathrm{mg} \cdot \mathrm{L}^{-1}[8]$.

At present, there are many methods used to treat eutrophication, which consist primarily of physical, chemical and biological methods [9-11]. Biological methods typically entail the use of aquatic plants to purify sewage, which has the advantages of simple operation and large economic and technical implementations. Biological treatment has become an important new technology for the remediation of polluted water [12]. The tolerance of plants to different pollutants and their removal abilities and mechanisms along with the survival and growth ability of plants under polluted environments are the theoretical and technical bases of phytoremediation. In the study of plant physiological ecology, pigment content, water content, nutrition status, photosynthetic rate and other parameters are important indicators of the physiological status of plants [13]. The root system of the plant can optimize the absorption and use of nutrients through its physiological and ecological adaptability [14]. The "red edge" of the blade reflection spectrum is sensitive to vegetation growth, which is defined as the largest slope in the reflectance spectrum of plants and would be beneficial for modelling nutrient fluxes [15].

Scirpus validus is an aquatic plant widely used in sewage treatment [16] that presents good removal rates of nutrient salt [17], heavy metals [18] and organic compounds [19]. For example, $S$. validus is effective at removing ammonia nitrogen and nitrate and at effectively promoting the transformation of nitrogen and significantly reduce the residence time of inorganic nitrogen in wetlands [20]. Li studied the purification effect and physiological characteristics of $S$. validus in wastewater treatment [13]. The results showed that $S$. validus could effectively remove ammonia nitrogen, and its net photosynthetic rate was higher in wastewater than in the controls. Fu showed that the water-purifying effect of S. validus was $74.41 \%$ and that the plant had a strong purifying effect on reclaimed water with a high salt content [21]. Therefore, studies on plant photosynthetic physiology and spectral characteristics that show the tolerant response of plants to different nitrate environments can provide a theoretical basis for developing methods to remediate nitrate pollution in waters using S. validus.

\section{Materials and Methods}

\section{Experimental Set-up}

In mid-March 2015, 150 robust, healthy $S$. validus plants were collected from South Lake Park for use in the experiment in Tai'an, Shandong Province, China. In the lab, sediment, plankton, withered and yellow leaves were removed from the root surfaces with tap water. Then the plants were transferred to 20 -L buckets containing $15 \mathrm{~L}$ of tap water. The plants underwent two weeks of cultivation and domestication in the artificial glasshouse of Shandong Agricultural University to become adapted to the greenhouse environment. After domestication, the plants were fit for the simulation test. The plants were monitored biweekly to observe the treatment levels and correct any deviations from the desired treatment levels.

\section{Nitrate and Water Level Treatments}

The culture solution was prepared from Hoagland culture solution with only $\mathrm{KNO}_{3}$ added. Seven nitrate concentrations were established: $0 \mathrm{mmol} \cdot \mathrm{L}^{-1}$, $0.5 \mathrm{mmol} \cdot \mathrm{L}^{-1}, 1.0 \mathrm{mmol} \cdot \mathrm{L}^{-1}, 2.5 \mathrm{mmol} \cdot \mathrm{L}^{-1}, 5 \mathrm{mmol} \cdot \mathrm{L}^{-1}$, $10 \mathrm{mmol} \cdot \mathrm{L}^{-1}$ and $20 \mathrm{mmol} \cdot \mathrm{L}^{-1}$, as based on a previous study [22]. The 20-L, blue plastic buckets were used for culture and each contained $15 \mathrm{~L}$ of nutrient solution. For each bucket, the plants (3 plants per bucket) were fixed to the top of the bucket with a foam board and covered with a black plastic bag to maintain the roots in a dark state. Each treatment included three replications (7 treatments $\times 3$ replications). The experiment lasted for 35 days. At the end of the experiment, photosynthetic indexes and spectral parameters were measured, after which the plants were harvested and washed three times with ultra-pure water. Their biomass (Fresh Weight, FW) and the nitrogen content were determined using chemical methods [23]. The length, volume, and diameter of the roots were simultaneously determined using the plant root analysis machine (WinRHIZO, Regent Instruments Company, Quebec, Canada), which can measure root length, volume, diameter, surface area, and projected area for washed roots.

\section{Determining Photosynthetic Indexes}

\section{Determining Photosynthetic Gas-Exchange Parameters}

Photosynthetic gas exchange parameters were measured at 08:00-11:30 each day. From the middle part of each test plant, 3 leaves showing ideal development were selected, and light response was measured using a CIRAS-2 portable photosynthesis system (Systems PP, USA). We applied photosynthetic active radiation (PAR) by using a light-emitting diode (LED) (range 0-2000 $\mu \mathrm{mol}$ (photon) $\mathrm{m}^{-2} \cdot \mathrm{s}^{-1}$; peak emission wavelength: red light (90\%): 620-630 $\mathrm{nm}$, and white light (10\%): 425-625 nm) at the following levels: 2000, 1800, 1600, 1400, 1200, 1000, 800, 600, 400, 200, 150, 100, 60, 30, and $0 \mu \mathrm{mol} \cdot \mathrm{m}^{-2} \cdot \mathrm{s}^{-1}$. Each PAR measurement was a duration of $120 \mathrm{~s}$, with three repeats. The air temperature of the leaf chamber was maintained at approximately $26 \pm 1.5^{\circ} \mathrm{C}$, the relative humidity was maintained at $60 \pm 5 \%$, and the $\mathrm{CO}_{2}$ concentration was $370 \pm 6 \mu \mathrm{mol} \cdot \mathrm{mol}^{-2}$. The following physiological and environmental parameters were automatically recorded: PAR $\left(\mu \mathrm{mol} \cdot \mathrm{m}^{-2} \cdot \mathrm{s}^{-1}\right)$, net photosynthetic rate $\left(P_{\mathrm{n}}, \mu \mathrm{mol} \cdot \mathrm{m}^{-2} \cdot \mathrm{s}^{-1}\right)$, transpiration rate $\left(E, \mathrm{mmol} \cdot \mathrm{m}^{-2} \cdot \mathrm{s}^{-1}\right)$, 
stomatal conductance $\left(G_{\mathrm{s}}, \mathrm{mmol} \cdot \mathrm{m}^{-2} \cdot \mathrm{s}^{-1}\right)$, intercellular $\mathrm{CO}_{2}$ concentration $\left(C_{\mathrm{i}}, \mu \mathrm{mol} \cdot \mathrm{mol}^{-1}\right)$, and air $\mathrm{CO}_{2}$ concentration $\left(C_{\mathrm{a}}, \mu \mathrm{mol} \cdot \mathrm{mol}^{-1}\right)$. Water-use efficiency (WUE, $\mu \mathrm{mol} \cdot \mathrm{mmol}^{-1}$ ) and stomatal limitation $\left(L_{\mathrm{s}}\right)$ were calculated as follows: $\mathrm{WUE}=P_{\mathrm{n}} / E, L_{\mathrm{s}}=1-C_{\mathrm{i}} / C_{\mathrm{a}}$ [24].

\section{Determination of Spectral Parameters}

\section{Spectral Parameter Data Acquisition}

A Unispec-SC (single channel) portable spectrometer produced by PP Systems (USA) was used to measure spectral reflectance in the different treatments; the parameters of band, sampling interval and resolving power were $310-1130 \mathrm{~nm}$ and $1 \mathrm{~nm}$, respectively. For each treatment, three samples were selected, and three leaves from each sample were measured. Corrections were made using a standard whiteboard. The average measurement value was recorded as the leaf spectral reflectance. The spectral reflectance data were input into Excel 2013.

\section{Data Processing}

After obtaining the average spectral reflectance, we calculated the differential spectral reflectance according to the following equation (1), which eliminates the spectral baseline translation to obtain the "trilateral parameter":

$$
\begin{gathered}
D_{\lambda_{i}}=\frac{\left|R_{\lambda(i+1)}-R_{\lambda(\mathrm{i}-1)}\right|}{2 \Delta \lambda} \\
\text { CHINDI }=\frac{R_{750}-R_{705}}{R_{750}+R_{705}} \\
\text { PRI }=\frac{R_{531}-R_{570}}{R_{531}+R_{570}} \\
\text { WI }=\frac{R_{900}}{R_{970}}
\end{gathered}
$$

...where $\lambda i$ is the value of band $\mathrm{i} ; R \lambda i$ is the spectral reflectance, and $\Delta \lambda$ is the difference between $\lambda(i-1)$ and $\lambda i$, which is determined by the sampling interval. ChINDI, PRI, WI and SDr/SDb represent the chlorophyll content, xanthophyll cycle, water content and ratio of the differential area of the red edge to the differential area of the blue edge of $S$. validus, respectively, where SDr is the sum of the first-order differential spectra in the $680-755 \mathrm{~nm}$ region, and SDb is the sum of first-order differential spectra in the 490-530-nm region [25].

\section{Data Analysis}

The data were entered into Microsoft Excel 2013 and Origin 9.0 spreadsheets. All representative values are presented as the mean and standard deviation (S.D.). Significant differences between treatments were determined by an analysis of variance (ANOVA) and the Duncan test as implemented in SAS 9.0. A P-value less than 0.05 was considered significant.

\section{Results and Discussion}

\section{Growth Measures}

Nitrate is the dominant form of the mineral $\mathrm{N}$ and is readily mobile in the xylem, little nitrate accumulation is beneficial to the growth of plants, but high nitrates are toxic to plants [26]. Excessive concentrations of nitrates do not entail an increase in the fresh weight of the plant [27] and caused a significant effect on stem [28] (Table 1).

The influences of the different nitrate treatments on new stem height, $\Delta$ root length, and FW are shown in Table 1. All of the values first increased and then decreased with increasing nitrate concentration, with the "watershed" concentration being $10 \mathrm{mmol} \cdot \mathrm{L}^{-1}$. Nitrate promoted the growth of $S$. validus at concentrations $<10 \mathrm{mmol} \cdot \mathrm{L}^{-1}$; at $10 \mathrm{mmol} \cdot \mathrm{L}^{-1}$, the fresh weight reached $43.83 \mathrm{~g}$, representing $46.10 \%$ and $34.65 \%$ increases over

Table 1. Effect of nitrate treatments on stem height, root length, and fresh weight of Scirpus validus. Values are the means of three replications \pm SD. Means in columns within the different concentrations of nitrate followed by different letters are significantly different (LSD test, $P<0.05$ ).

\begin{tabular}{|c|c|c|c|}
\hline Nitrate $/ \mathrm{mmol} \cdot \mathrm{L}^{-1}$ & New stem height/cm & Fresh weight/g & $\Delta$ Root length/cm \\
\hline 0 & $30.56 \pm 1.48 \mathrm{c}$ & $32.55 \pm 4.45 \mathrm{c}$ & $9.65 \pm 2.81 \mathrm{~b}$ \\
\hline 0.5 & $31.07 \pm 2.11 \mathrm{c}$ & $35.13 \pm 2.38 \mathrm{bc}$ & $9.66 \pm 1.43 \mathrm{~b}$ \\
\hline 1.0 & $31.25 \pm 3.81 \mathrm{c}$ & $36.20 \pm 2.60 \mathrm{bc}$ & $10.57 \pm 1.35 \mathrm{~b}$ \\
\hline 2.5 & $40.70 \pm 1.03 \mathrm{ab}$ & $37.10 \pm 7.81 \mathrm{bc}$ & $14.86 \pm 1.19 \mathrm{a}$ \\
\hline 5 & $43.38 \pm 3.12 \mathrm{a}$ & $41.87 \pm 3.14 \mathrm{ab}$ & $17.33 \pm 0.25 \mathrm{a}$ \\
\hline 10 & $44.86 \pm 3.18 \mathrm{a}$ & $43.83 \pm 4.40 \mathrm{a}$ & $18.07 \pm 2.49 \mathrm{a}$ \\
\hline 20 & $36.71 \pm 3.33 \mathrm{~b}$ & $38.17 \pm 2.91 \mathrm{bc}$ & $10.34 \pm 2.00 \mathrm{~b}$ \\
\hline
\end{tabular}


Table 2. Effect of nitrate treatments on the total root surface area, total root volume, and average diameter of Scirpus validus. Values are the means of three replications \pm SD. Means in columns within the different concentrations of nitrate followed by different letters are significantly different (LSD test, $P<0.05$ ).

\begin{tabular}{|c|c|c|c|}
\hline Nitrate $/ \mathrm{mmol} \cdot \mathrm{L}^{-1}$ & Total root surface $\mathrm{area} / \mathrm{cm}^{2}$ & Total root volume $/ \mathrm{cm}^{3}$ & Average diameter $/ \mathrm{mm}$ \\
\hline 0 & $2.21 \pm 0.3 \mathrm{c}$ & $0.02 \pm 0.001 \mathrm{~g}$ & $0.24 \pm 0.01 \mathrm{a}$ \\
\hline 0.5 & $6.36 \pm 0.47 \mathrm{~cd}$ & $0.05 \pm 0.001 \mathrm{e}$ & $0.30 \pm 0.00 \mathrm{~d}$ \\
\hline 1.0 & $8.57 \pm 0.44 \mathrm{bc}$ & $0.05 \pm 0.002 \mathrm{~d}$ & $0.38 \pm 0.02 \mathrm{c}$ \\
\hline 2.5 & $9.52 \pm 3.21 \mathrm{~b}$ & $0.08 \pm 0.003 \mathrm{c}$ & $0.38 \pm 0.01 \mathrm{c}$ \\
\hline 5 & $11.00 \pm 1.53 \mathrm{~b}$ & $0.08 \pm 0.009 \mathrm{~b}$ & $0.41 \pm 0.04 \mathrm{~b}$ \\
\hline 10 & $16.54 \pm 1.27 \mathrm{a}$ & $0.10 \pm 0.007 \mathrm{a}$ & $0.47 \pm 0.02 \mathrm{a}$ \\
\hline 20 & $5.20 \pm 0.47 \mathrm{~d}$ & $0.05 \pm 0.002 \mathrm{f}$ & $0.29 \pm 0.01 \mathrm{~d}$ \\
\hline
\end{tabular}

the initial and control values, respectively. In addition, at $10 \mathrm{mmol} \cdot \mathrm{L}^{-1}, \Delta$ root length and new stem height were 18.07 and $44.86 \mathrm{~cm}$, respectively, which represent $87.25 \%$ and $46.79 \%$ increases compared with the control levels, respectively. In contrast, at $20 \mathrm{mmol} \cdot \mathrm{L}^{-1}$, the fresh weight, new stem height and $\Delta$ root length declined by $12.91 \%, 18.17 \%$ and $42.79 \%$, respectively, compared with that at $10 \mathrm{mmol} \cdot \mathrm{L}^{-1}$.

\section{Root Measurements}

Roots are the major organs for uptake of nitrate, which affect some morphological characteristics of plants [29] and increase the root surface area, average diameter and volume [30, 31]. These imbalances will affect root function and cause premature aging in the aerial parts of the leaves. Under such conditions, the plant will adapt by increasing the root-shoot ratio, stimulating lateral root growth, and reducing the number of axes [32].

Table 2 shows the influences of different nitrate concentrations on the root surface area, average diameter and volume in $S$. validus. All increased significantly with increasing nitrate concentrations. At $10 \mathrm{mmol} \cdot \mathrm{L}^{-1}$, root surface area, average diameter and volume were $16.54 \mathrm{~cm}^{2}, 0.47 \mathrm{~mm}$, and $0.098 \mathrm{~cm}^{3}$, respectively.
These values were 7.50, 1.99 and 5.76 times, respectively, those of the control treatment. At $20 \mathrm{mmol} \cdot \mathrm{L}^{-1}$, the values of the three measures decreased. Root surface area was reduced to $5.20 \mathrm{~cm}^{2}$, representing a $68.58 \%$ decrease, even though this value was higher (2.36 times greater) than that of the control treatment $(P<0.05)$. In addition, at $20 \mathrm{mmol} \cdot \mathrm{L}^{-1}$, root average diameter was only $0.29 \mathrm{~mm}$, i.e., $61.65 \%$ of the maximum value, and root volume was significantly reduced to only $45.92 \%$ of the maximum value.

In this study, in the range of $0-10 \mathrm{mmol} \cdot \mathrm{L}^{-1}$ of nitrate, the root growth of the plants increased with increasing nitrate concentration. This result indicates that the ability to utilize nitrate is positively correlated with root length, surface area, volume, and average diameter. However, at $20 \mathrm{mmol} \cdot \mathrm{L}^{-1}$, the root parameters showed various degrees of decline, decreasing by more than $40 \%$. These findings are consistent with those in Rhus typhina and Pinus ponderosa [33], Nicotiana tabacum [34], Populus [31], and Triticum aestivum [35]. This change affects the nitrate uptake rate of the roots, thereby affecting the accumulation of nitrogen (Fig. 3). The main reason for these results is that low concentrations of nitrate stimulate the elongation of lateral root [36], whereas high nitrate concentrations increase abscisic acid levels in root tips [37] and inhibit

Table 3. Total nitrogen, ammonium, and nitrate contents of Scirpus validus under different nitrate concentrations. Values are the means of three replications \pm SD. Means in columns within the different concentrations of nitrate followed by different letters are significantly different (LSD test, $P<0.05$ ).

\begin{tabular}{|c|c|c|c|}
\hline Nitrate $/ \mathrm{mmol} \cdot \mathrm{L}^{-1}$ & Ammonium $/ \mathrm{mg} \cdot \mathrm{g}^{-1}$ & Nitrate $/ \mathrm{mg} \cdot \mathrm{g}^{-1}$ & Total nitrogen $/ \mathrm{mg} \cdot \mathrm{g}^{-1}$ \\
\hline 0 & $3.43 \pm 0.10 \mathrm{a}$ & $4.64 \pm 0.70 \mathrm{~b}$ & $8.06 \pm 0.79 \mathrm{~b}$ \\
\hline 0.5 & $3.29 \pm 0.69 \mathrm{a}$ & $5.21 \pm 1.25 \mathrm{~b}$ & $8.50 \pm 0.61 \mathrm{~b}$ \\
\hline 1.0 & $3.50 \pm 0.54 \mathrm{a}$ & $6.58 \pm 0.84 \mathrm{ab}$ & $10.08 \pm 1.01 \mathrm{ab}$ \\
\hline 2.5 & $3.27 \pm 0.89 \mathrm{a}$ & $7.87 \pm 1.47 \mathrm{a}$ & $11.14 \pm 1.66 \mathrm{a}$ \\
\hline 5 & $3.31 \pm 1.12 \mathrm{a}$ & $8.96 \pm 0.12 \mathrm{a}$ & $12.27 \pm 1.16 \mathrm{a}$ \\
\hline 10 & $3.85 \pm 0.85 \mathrm{a}$ & $7.90 \pm 0.97 \mathrm{a}$ & $11.74 \pm 1.61 \mathrm{a}$ \\
\hline 20 & $3.85 \pm 0.89 \mathrm{a}$ & $7.54 \pm 0.21 \mathrm{ab}$ & $11.39 \pm 1.07 \mathrm{a}$ \\
\hline
\end{tabular}




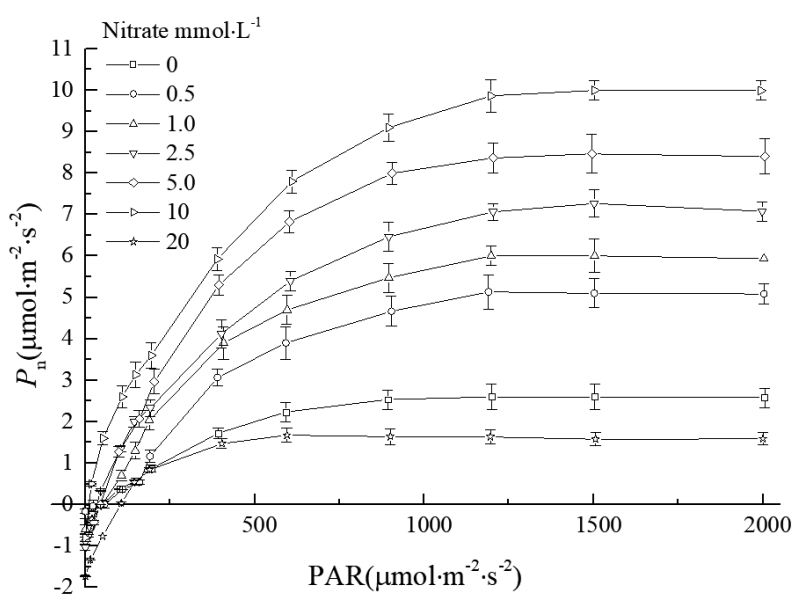

Fig. 1. Photosynthetic rate-light response curves and simulation of Scirpus validus under different nitrate concentrations. Values are the means of three replications $\pm \mathrm{SD}$.

this activity [38]; this inhibition is more evident at concentrations of $10 \mathrm{mmol} \cdot \mathrm{L}^{-1}$ or more, which leads to the reduced accumulation of nitrogen, especially at $20 \mathrm{mmol} \cdot \mathrm{L}^{-1}$. These observations suggest that the ability of plants to utilize nitrate varies not only with the nitrogen content of the plant but also with root length, diameter, volume and surface area.

\section{$\mathrm{N}$ content}

With increasing nitrate concentration, total nitrogen, nitrate and ammonium of $S$. validus first increased and then decreased; the differences in ammonium content were not significant $(P>0.05)$, whereas those in total nitrogen and nitrate content were significant (Table 3). Nitrate had the largest contribution to the total nitrogen content of $S$. validus. At $5 \mathrm{mmol} \cdot \mathrm{L}^{-1}$, total nitrogen reached a maximum of $12.27 \mathrm{mg} \cdot \mathrm{g}^{-1}$, 1.52 times higher than the value in control plants. At $20 \mathrm{mmol} \cdot \mathrm{L}^{-1}$, total nitrogen content decreased by $13.67 \%$ to 1.31 times the control level. Nitrate content showed a similar trend as total nitrogen. At $5 \mathrm{mmol} \cdot \mathrm{L}^{-1}$, the maximum value of $8.96 \mathrm{mg} \cdot \mathrm{g}^{-1}$ was reached, which was 1.93 times the control level. At $20 \mathrm{mmol} \cdot \mathrm{L}^{-1}$, the minimum content of $7.54 \mathrm{mg} \cdot \mathrm{g}^{-1}$ was observed, which was 1.63 times that of the control plants. In contrast, the ammonium content of $S$. validus showed little change with increasing nitrate concentration, ranging from 3.05-3.86 $\mathrm{mg} \cdot \mathrm{g}^{-1}$.

\section{Light Response Parameters}

Photosynthesis is the basis for the physiological processes underlying plant activity, growth and development [39] and can serve as an indicator of plant growth. The role of nitrate as an osmoticum affecting stomatal opening was elucidated, stomatal movement is highly regulated by multiple pathways to reduce excess water loss and maintain $\mathrm{CO}_{2}$ uptake for photosynthesis [40], and the nitrate uptake and assimilation depends on photosynthesis [41]. Nitrate can promote the photosynthetic rate of plants and increase electron fixation of $\mathrm{CO}_{2}$ [42] and stimulate nitrate assimilation into amino acid [43], but in high $\mathrm{NO}_{3}^{-}$supply condition, the photosynthesis is reduced and a substantial proportion of the $\mathrm{NO}_{3}^{-}$taken up is not assimilated [44]. However, at high nitrate concentrations, the lack of water in plant tissue will cause stomatal closure, impairments to chlorophyll, light-related enzyme inactivation or denaturation, and photosynthetic rate and assimilation reductions and the deceased PRI.

As shown in Fig. 1 and Table 4, both the process and characteristic parameters of the optical response of photosynthesis in leaves of $S$. validus differed significantly among the different nitrate concentrations. With increasing nitrate concentrations, the lightsaturated net photosynthetic rate $\left(P_{\mathrm{n} \max }\right)$, light saturation point $(L S P)$ and quantum yield at the light compensation point $(\Phi c)$ first increased and then decreased. However, the light compensation point $(L C P)$ and respiration rate $\left(R_{\mathrm{d}}\right)$ showed no obvious changes with increasing nitrate concentration. The decrease of $L S P$ and the increase of $L C P$ in plant photosynthesis indicate that the utilization ability and degree of light energy (strong light and dim light) decreased. The decrease of $\Phi$ indicates that the conversion efficiency of light energy utilization under low light intensity is decreased [45]. The decrease of $P_{\text {nmax }}$ and the increase of $R_{\mathrm{d}}$ indicate that the synthesis

Table 4. Model-fitted values of photosynthesis-light response parameters of Scirpus validus.

\begin{tabular}{|c|c|c|c|c|c|c|c|}
\hline Light response model & $\begin{array}{c}\text { Nitrate concentration } \\
\left(\mathrm{mmol} \cdot \mathrm{L}^{-1}\right)\end{array}$ & $\Phi$ & $\mathrm{LSP}$ & $\mathrm{P}_{\mathrm{nmax}}$ & $\mathrm{LCP}$ & $\mathrm{R}_{\mathrm{d}}$ & $\mathrm{R}^{2}$ \\
\hline \multirow{5}{*}{$\begin{array}{c}\text { Rectangular hyperbolic } \\
\text { modified model }\end{array}$} & 0 & 0.0053 & 893 & 2.6 & 34.58 & -0.18 & 0.9913 \\
\cline { 2 - 8 } & 0.5 & 0.0061 & 1190 & 5.1 & 39.60 & -0.25 & 0.8994 \\
\cline { 2 - 8 } & 1.0 & 0.0137 & 1198 & 6.08 & 47.99 & -0.66 & 0.9941 \\
\cline { 2 - 9 } & 2.5 & 0.018 & 1204 & 7.27 & 43.99 & -0.79 & 0.9607 \\
\cline { 2 - 9 } & 5.0 & 0.0188 & 1495 & 8.47 & 44.54 & -0.837 & 0.9931 \\
\cline { 2 - 8 } & 10 & 0.0245 & 1503 & 10 & 28.38 & -0.70 & 0.9598 \\
\hline
\end{tabular}



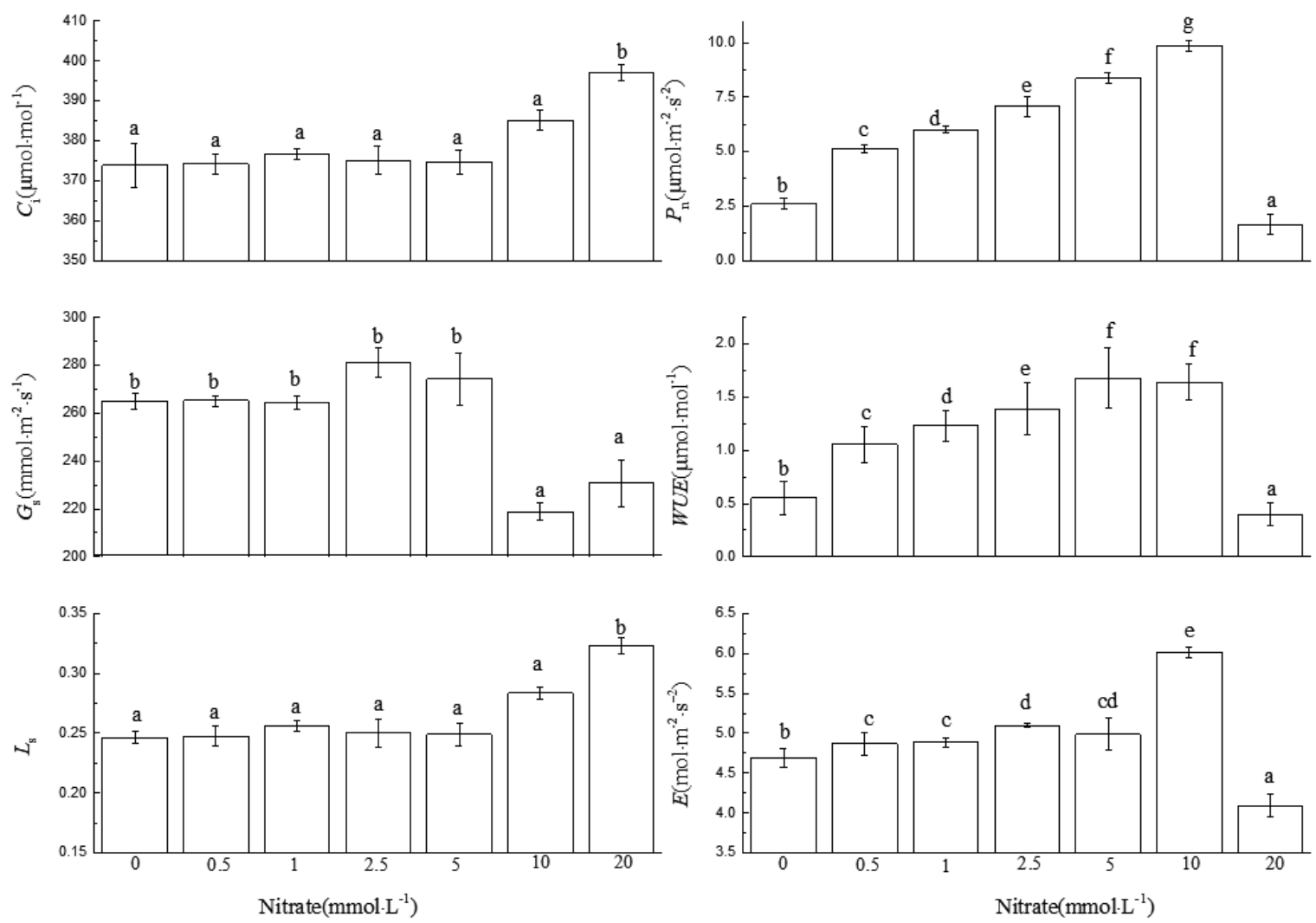

Fig. 2. The response of photosynthetic physiological parameters of Scirpus validus to nitrate concentrations (mean \pm SD) under the same photosynthetically active radiation $\left(\mathrm{PAR}=1200 \mu \mathrm{mol} \cdot \mathrm{m}^{-2} \cdot \mathrm{s}^{-1}\right)$. Values are the means of three replications $\pm \mathrm{SD}$. Means in columns within the different concentrations of nitrate followed by different letters are significantly different $(P<0.05)$.

ability of organic compounds decreased and respiration consumption increased. Taken together, the results show that the highest concentration of nitrate had an inhibitory effect on photosynthetic efficiency and on light energy utilization efficiency in the leaves of S. validus. $P_{\text {max }}$ was lowest at the nitrate concentration of $20 \mathrm{mmol} \cdot \mathrm{L}^{-1}$, indicating that photosynthesis is sensitive to nitrate stress.

\section{Photosynthetic Gas-Exchange Parameters}

The variation in gas exchange parameters is shown in Fig. 2. With increasing nitrate concentration, $P_{\mathrm{n}}, E$, $G$, and WUE first increased and then decreased. At $0-10 \mathrm{mmol} \cdot \mathrm{L}^{-1}$, they increased with increasing nitrate concentration. However, at $20 \mathrm{mmol} \cdot \mathrm{L}^{-1}, P_{\mathrm{n}}$ decreased significantly to $1.63 \mu \mathrm{mol} \cdot \mathrm{m}^{-2} \cdot \mathrm{s}^{-2}$, which was decreased by $37.18 \%$ and $83.45 \%$ compared with the control and highest values, respectively. $E$ and WUE decreased significantly to $4.09 \mathrm{mmol} \cdot \mathrm{m}^{-2} \cdot \mathrm{s}^{-1}$ and $0.40 \mu \mathrm{mol} \cdot \mathrm{mol}^{-1}$, respectively, which correspond to $68.05 \%$ and $72.06 \%$, respectively, of the control values. $G_{\mathrm{s}}$ first increased with increasing nitrate concentration $\left(<5 \mathrm{mmol} \cdot \mathrm{L}^{-1}\right)$ but then decreased to $218.75 \mathrm{mmol} \cdot \mathrm{m}^{-2} \cdot \mathrm{s}^{-1}$ at $10 \mathrm{mmol} \cdot \mathrm{L}^{-1}$. $C_{i}$ and $L_{s}$ continued to increase with increasing nitrate concentration; at $20 \mathrm{mmol} \cdot \mathrm{L}^{-1}, C_{i}$ and $L_{s}$ reached $397 \mu \mathrm{mol} \cdot \mathrm{mol}^{-1}$ and 0.32 , respectively, representing increases of $6.2 \%$ and $31.38 \%$ compared with the control levels.

The observations of photosynthetic gas exchange in the leaves (Fig. 2) show that at a fixed light intensity, $P_{\mathrm{n}}$, $E, G_{s}, L S P$ and $P_{\text {nmax }}$ had greater degrees of decline in the nitrate treatments compared with the control values (Table 4 and Fig. 2). These findings suggest that high concentrations of nitrate $\left(\geq 10 \mathrm{mmol} \cdot \mathrm{L}^{-1}\right)$ can inhibit photosynthesis, mainly due to the effects of infiltrated nitrate on transmembrane transport of substances of plant cells [44] or the nitrogen content of leaves [46]. When photosynthesis increases, the availability of both carbohydrate and organic acids rises and these accumulate in the vacuole, constituting an alternative to the osmoregulatory function of nitrate [27].

In this study, nitrate stress significantly inhibited $\Phi$, especially at $20 \mathrm{mmol} \cdot \mathrm{L}^{-1}$ (Table 4). At this concentration, light energy utilization decreased, and $P_{\text {nmax }}$ decreased rapidly (Fig. 2). The reduction in photosynthetic rate was mainly due to stomatal and non-stomatal limitation [47]. Stomatal limitation is caused by a decrease in the $\mathrm{CO}_{2}$ supply to chloroplasts, which result from decreased $C_{i}$ and reduced stomatal aperture, whereas non-stomatal limitation is due to stomatal diffusion resistance involving mesophyll cells. The results show that at low nitrate concentrations, $G_{\mathrm{s}}$ decreased, resulting in $C_{i}$ decline; however, at much higher nitrate concentrations, 


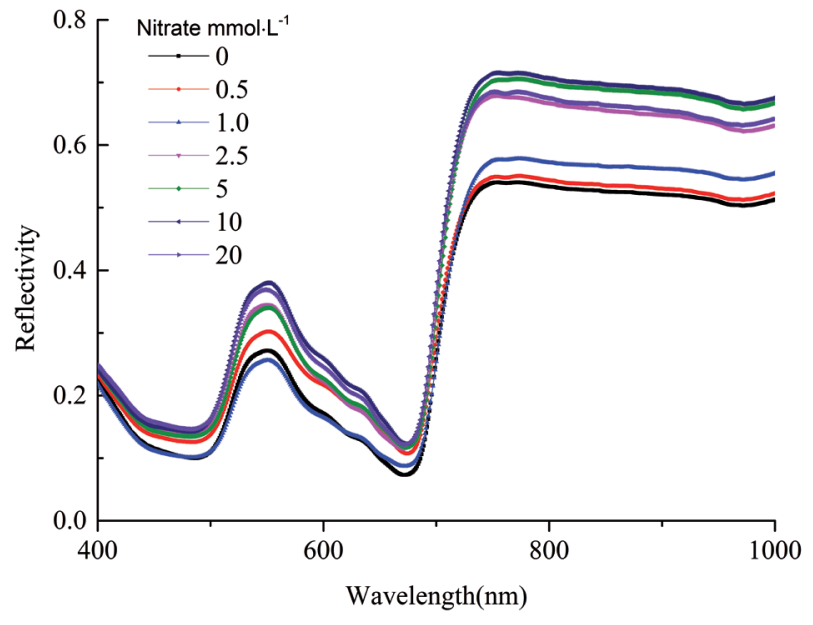

Fig. 3. The reflection spectrum of Scirpus validus under different nitrate concentrations.

$C_{i}$ and $L_{s}$ increased. These results indicate that the effect of nitrate on photosynthetic rate occurs primarily through stomatal limitation. Li reported similar results: WI and WUE are low, and the plant opens the stomata to maintain the $\mathrm{CO}_{2}$ supply and normal growth [48]. This indicated high $\mathrm{NO}_{3}^{-}$can reduce the stomatal aperture and transpiration rates [44].

\section{Spectral Parameters}

Several spectral models have been established to characterize the physiological state of plants [25, 49, $50]$ and to monitor plant nutrition $[15,51]$. The spectral reflectance values of the $S$. validus leaves under different treatments are shown in Fig. 3. In the wavelength range of 400-1000 $\mathrm{nm}$, a strong reflectance in the visible spectral region was observed from the leaves from all of the treatments, with strong reflectance peaks at $550 \mathrm{~nm}$. At $700-750 \mathrm{~nm}$, the reflection rapidly increased; at 750-1000 $\mathrm{nm}$, the rate of increase slowed, with the values eventually forming a high "reflection platform". At $550 \mathrm{~nm}$, where the reflection intensity decreased in the order $10 \mathrm{mmol} \cdot \mathrm{L}^{-1}>20 \mathrm{mmol} \cdot \mathrm{L}^{-1}>$ $2.5 \mathrm{mmol} \cdot \mathrm{L}^{-1}>5 \mathrm{mmol} \cdot \mathrm{L}^{-1}>0.5 \mathrm{mmol} \cdot \mathrm{L}^{-1}>0 \mathrm{mmol} \cdot \mathrm{L}^{-1}$ $>1.0 \mathrm{mmol} \cdot \mathrm{L}^{-1}$, the reflection intensity also increased substantially with increasing nitrate concentration, and no variations were shown. In the 750-1000-nm range, where the reflection intensity was in the order $10 \mathrm{mmol} \cdot \mathrm{L}^{-1}>5 \mathrm{mmol} \cdot \mathrm{L}^{-1}>20 \mathrm{mmol} \cdot \mathrm{L}^{-1}>2.5 \mathrm{mmol} \cdot \mathrm{L}^{-1}$ $>1.0 \mathrm{mmol} \cdot \mathrm{L}^{-1}>0.5 \mathrm{mmol} \cdot \mathrm{L}^{-1}>0 \mathrm{mmol} \cdot \mathrm{L}^{-1}$, the reflection strength tended to increase substantially with increasing nitrate concentration. In the infrared range, the direct reflection spectrum showed obvious variation. This result indicates that it is possible to use infrared light Poor's diagnosis to determine the influence of nitrate on $S$. validus [52].
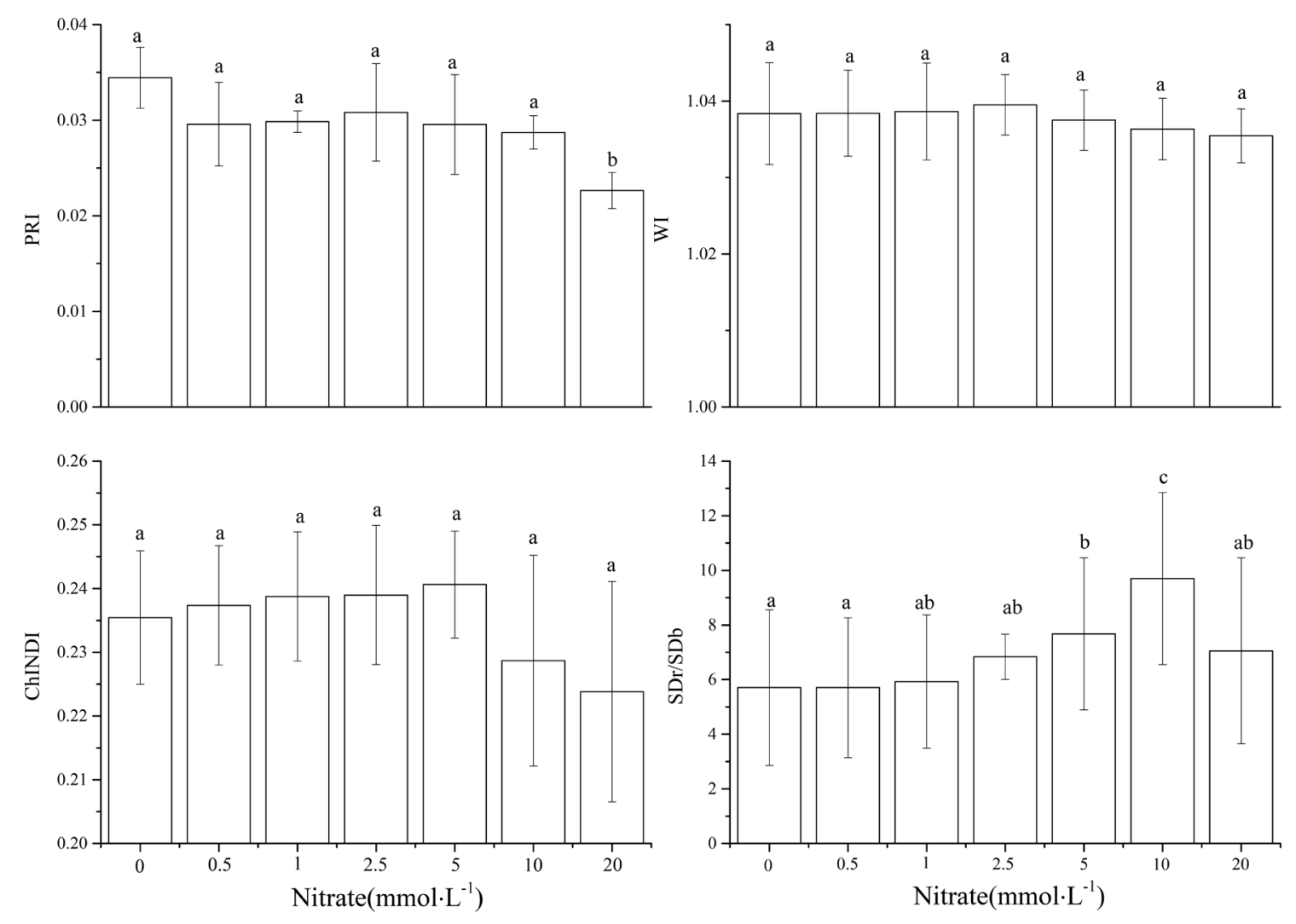

Fig. 4. The response of spectral parameters (PRI, WI, ChINDI, SDr/SDb) of Scirpus validus to nitrate concentrations. Values are the means of three replications \pm SD. Means in columns within the different concentrations of nitrate followed by different letters are significantly different $(P<0.05)$. 
Fig. 4 shows the influences of different nitrate concentrations on PRI, SDr/SDb, WI and ChlNDI. Generally, these parameters first increased and then decreased with increasing nitrate concentrations. WI and ChlNDI showed no pronounced changes, unlike PRI and SDr/SDb. PRI declined as nitrate concentration increased and showed no obvious variation in the range of $0-10 \mathrm{mmol} \cdot \mathrm{L}^{-1}$; however, at $20 \mathrm{mmol} \cdot \mathrm{L}^{-1}$, the PRI value was 0.02 , which was $65.74 \%$ that of the control value. $\mathrm{SDr} / \mathrm{SDb}$ showed a different pattern from PRI in the range of $0-10 \mathrm{mmol} \cdot \mathrm{L}^{-1}$; at $10 \mathrm{mmol} \cdot \mathrm{L}^{-1}, \mathrm{SDr} / \mathrm{SDb}$ was 9.70, which was 1.70 times that of the control value. SDr/SDb subsequently decreased to 7.05 , which was $72.68 \%$ the value at $10 \mathrm{mmol} \cdot \mathrm{L}^{-1}$ and 1.24 times the control value.

The $\mathrm{SDr} / \mathrm{SDb}$ was previously found to be significantly and positively correlated with plant nitrogen content. With increasing nitrate concentration, the $\mathrm{SDr} / \mathrm{SDb}$ increased and then decreased, likely reflecting the rapid growth of the plant, which requires nitrogen; alternatively, the pattern of $\mathrm{SDr} / \mathrm{SDb}$ might be related to changes in $\mathrm{K}^{+}$[53]. At $20 \mathrm{mmol} \cdot \mathrm{L}^{-1}$, $\mathrm{SDr} / \mathrm{SDb}$ decreased, and $\mathrm{SDr} / \mathrm{SDb}$ and total nitrogen content were $72.71 \%$ and $92.85 \%$, respectively, of the highest values. This SDr/SDb decrease occurred because the plant accumulated more nitrate with increasing nitrate concentration, leading to a decrease in nitrogen metabolism activity and an increase in ammonium content (Fig. 3), which can be toxic.

ChlNDI characterizes the chlorophyll content, and nitrogen is an element that forms part of the synthesis of chlorophyll. Chlorophyll is the material basis of light absorption, transmission and conversion [54]. The results showed that chlorophyll content changed with increasing nitrate concentration. At $20 \mathrm{mmol} \cdot \mathrm{L}^{-1}$, the lowest chlorophyll content was observed, which was $95.06 \%$ that of the control value. This difference was not significant, similar to the results of Gromaz [27]. This result was obtained because nitrate stress can inhibit the absorption of $\mathrm{Mg}^{2+}$, which in turn will cause a decrease in plant chlorophyll content.

\section{Conclusions}

The effects of different levels of nitrate stress on the growth, photosynthesis characteristics and spectral parameters of $S$. validus were investigated to elucidate the mechanisms of nitrate damage to plants and the adaptive physiological responses of plants to nitrate stress. The important findings were as follows. The inhibitory effects of nitrate stress on S. validus growth were greater at concentrations higher than $10 \mathrm{mmol} \cdot \mathrm{L}^{-1}$. Nitrate concentration greater than $10 \mathrm{mmol} \cdot \mathrm{L}^{-1}$ inhibited the growth of $S$. validus; specifically, the fresh weight, new stem height, $\Delta$ root length, surface area, and root average diameter and volume were reduced. Nitrate stress increased the level of ammonium in the plants, whereas the total nitrogen and nitrate nitrogen were reduced. Under stress $\left(\geq 10 \mathrm{mmol} \cdot \mathrm{L}^{-1}\right)$, nitrate damaged the photosynthetic system and highly reduced the net photosynthetic rate, transpiration rate, quantum yield at the light compensation point, light saturation point, and lightsaturated net photosynthetic rate. Furthermore, nitrate increased the stomatal limitation and stomatal conductance and influenced spectral parameters, e.g., reduced both PRI and SDr/SDb. The inhibitory effect of nitrate was most pronounced at $20 \mathrm{mmol} \cdot \mathrm{L}^{-1}$ $(P<0.05)$, primarily due to penetration and non-stomatal limitation.

This study identified the physiological responses of $S$. validus to nitrate stress. The observed changes in physiological indices in $S$. validus, including photosynthetic parameters and spectral indicators, suggest that nitrate can inhibit root growth, differentiation and photosynthesis in plants, leading to an overall reduction in growth. Our study also shows that near-infrared light can be used as a diagnostic tool for measuring nitrate stress.

\section{Abbreviations}

PAR, photosynthetic active radiation;

$\boldsymbol{E}$, transpiration rate;

$\boldsymbol{G}_{\mathbf{s}}$, stomatal conductance;

$C_{\mathrm{i}}$, intercellular $\mathrm{CO}_{2}$ concentration;

$\boldsymbol{C}_{\mathrm{a}}$, air $\mathrm{CO}_{2}$ concentration;

WUE, Water-use efficiency;

$\boldsymbol{L}_{\mathrm{s}}$ stomatal limitation;

$\boldsymbol{P}_{\mathrm{n}}$, net photosynthetic rate;

$\boldsymbol{L S} \boldsymbol{P}$, light saturation point;

$\boldsymbol{L C P}$, light compensation point;

$\boldsymbol{P}_{\text {nmax }}$, light-saturated net photosynthetic rate;

ChINDI, chlorophyll content;

WI, water content;

PRI, xanthophyll cycle index;

$\mathbf{S D r} / \mathbf{S D b}$, ratio of the differential area of the red edge to that of the blue edge

\section{Acknowledgements}

This research was financially supported by the Forestry Industry Research Special Funds for Public Welfare Projects (201504406; "Study and Demonstration of Re-Vegetation and Restoration in an Opencast Coal Mine"), the National Natural Science Foundation of China (No. 31700553, "Study on mechanism of nitrogen assimilation of poplar in response to the soil phenolic acid stress"), and the Natural Science Foundation of Shandong Province (approval No. ZR2015CM021; "The mechanism of purifying dyecontaining wastewater by phytoremediation". 


\section{Conflict of Interest}

The authors declare no conflict of interest.

\section{References}

1. MAHEAUX H., LEAVITT P.R., JACKSON L.J. Asynchronous onset of eutrophication among shallow prairie lakes of the northern great plains, Alberta, Canada. Global Change Biology 22, 271, 2016.

2. The Ministry of Water Resources of the People's Republic of China. Water Resources Bulletin 2016. The Ministry of Water Resources of the People's Republic of China, Beijing, 2016.

3. WANG X.Y., SUN M.J., XIE M.J., LIU M., LUO L., LI P.F., KONG F.X. Differences in microcystin production and genotype composition among Microcystis colonies of different sizes in Lake Taihu. Water Research 47, 5659, 2013.

4. COPETTI D., FINSTERLE K., MARZIALI L., STEFANI F., TARTARI G., DOUGLAS G., REITZEL K., SPEARS B.M., WINFIELD I.J., CROSA G., D'HAESE P., YASSERI S., LURLING M. Eutrophication management in surface waters using lanthanum modified bentonite: a review. Water Research 97, 162, 2016.

5. FERNANDEZ PINILLA R. The nitrogen cycling in water of the coastal lafoon of Marmenor and its relationship with the eutrophication process. Farmantra 5, 1, 2018.

6. World Health Organization. Regional Office for Europe. Health Hazards from Nitrates in Drinking-Water. Environmental Health (WHO-EURO). World Health Organization, Geneva, 1985.

7. WEITZBERG E., LUNDBERG J.O. Novel aspects of dietary nitrate and human health. Annual Review of Nutrition 33, 129, 2013.

8. World Health Organization. Guidelines for DrinkingWater Quality. Health Criteria and Other Supporting Information. World Health Organization, Geneva, 1998.

9. WANG T., JIN X., CHEN Z., MEGHARAJ M., NAIDU R. Green synthesis of Fe nanoparticles using eucalyptus leaf extracts for treatment of eutrophic wastewater. Science Total Environment 466-467, 210, 2014.

10. WAAJEN G., VAN OOSTERHOUT F., DOUGLAS G., LURLING M. Management of eutrophication in Lake De Kuil (The Netherlands) using combined flocculantLanthanum modified bentonite treatment. Water Research 97, 83, 2016

11. FANG T., BAO S., SIMA X., JIANG H., ZHU W., TANG W. Study on the application of integrated eco-engineering in purifying eutrophic river waters. Ecology Engineering 94, 320, 2016.

12. HUANG X., XIANG G.M. Application and research on treatment of urban eutrophic lake water by combined constructed wetlands system. Environmental Science \& Technology 9, 126, 2013.

13. LI L.S., NI X.L., LI Z.G., LI J. Growth characteristics and sewage cleaning effect of five wetland plants. Journal of Agro-Environment Science 32, 1625, 2013.

14. OKUSHIMA Y., INAMOTO H., UMEDA M. A high concentration of nitrate causes temporal inhibition of lateral root growth by suppressing cell proliferation. Plant Biotechnology 28, 413, 2011.

15. ZHAO Y.T., LI A., YAN E.R. The plant economics spectrum is structured by leaf habits and growth forms across subtropical species. Tree Physiology 37, 173, 2017.

16. ZHANG C.B., LIU W.L., PAN X.C., GUAN M., LIU S.Y., GE Y., CHANG J. Comparison of effects of plant and biofilm bacterial community parameters on removal performances of pollutants in floating island systems. Ecology Engineering 73, 58, 2014.

17. WU H., ZHANG J., LI P., ZHANG J., XIE H., ZHANG B. Nutrient removal in constructed microcosm wetlands for treating polluted river water in northern China. Ecology Engineering 37, 560, 2011.

18. RYCEWICZ-BORECKI M., MCLEAN J.E., DUPONT R.R. Bioaccumulation of copper, lead, and zinc in six macrophyte species grown in simulated stormwater bioretention systems. Journal of Environmental Management 166, 267, 2016.

19. ZHAO L., JIANG J., CHEN C., ZHAN S., YANG J., YANG S. Efficiency and mechanism of the phytoremediation of decabromodiphenyl ether-contaminated sediments by aquatic macrophyte Scirpus validus. Environmental Science \& Pollution Research International 24, 12949, 2017.

20. WAN X.H., LI X.D., WANG Y.C., LU J., ZHAO Y.Y., LIU L.H., ZHOU H.D. Simulation of removal ammonia and nitrate from wetlands constructed by different hydrophytes. Journal of Lake Sciences 20, 327, 2008.

21. FU C.P., TANG Y.P., YAN Y.R., CHEN X.J., Li J.H. Study on effect of Scirpus tabernaemontani gmel on purification of reclaimed water with high salt. China Water \& Wastewater 22, 40, 2006.

22. ZHANG H.M., FORDE B.G. Regulation of Arabidopsis root development by nitrate availability. Journal of Experimental Botany 51, 51, 2000.

23. LV W.X., GE Y., WU J.Z., CHANG J. Study on the method for the determination of nitric nitrogen, ammoniacal nitrogen and total nitrogen in plant. Spectroscopy \& Spectral Analysis 24, 204, 2004.

24. RADWAN D.E.M., FAYEZ K.A. Photosynthesis, antioxidant status and gas-exchange are altered by glyphosate application in peanut leaves. Photosynthetica 54, 307, 2016.

25. FENG W., ZHU Y., CAO W.X., ZHU Y.J., GUO T.C. Monitoring grain protein accumulation dynamics with canopy reflectance spectra in wheat. Acta Agronomica Sinica 35, 1320, 2009.

26. SAIZ-FERNANDEZ I., DE DIEGO N., SAMPEDRO M. C., MENA-PETITE A., ORTIZ-BARREDO A., LACUESTA M. High nitrate supply reduces growth in maize, from cell to whole plant. Journal of Plant Physiology 173, 120, 2015.

27. GROMAZ A., TORRES J.F., BAUTISTA A.S., PASCUAL B., LÓPEZGALARZA S., MAROTO J.V. Effect of different levels of nitrogen in nutrient solution and crop system on nitrate accumulation in endive. Journal of Plant Nutrition 40 (2), 2017.

28. DIEGO DE MELLO CONDE DE BRITO, CARLOS DIEGO DOS SANTOS, FABÍOLA VIEIRA GONCALVES, ROSANE NORA CASTRO, SONIA RRGINA DE SOUZA. Effects of nitrate supply on plant growth, nitrogen, phosphorus and potassium accumulation, and nitrate reductase activity in crambe. Journal of Plant Nutrition 36 (2), 275, 2013.

29. LI S.X., WANG Z.H., STEWART B.A. Chapter Five - Responses of Crop Plants to Ammonium and Nitrate N. Advances in Agronomy. Elsevier Science \& Technology. 2013. 
30. CHEN H.B., WEI X., WANG J., WANG Z.Q. Morphological and anatomical responses of Fraxinus mandshurica seedling roots to different nitrogen concentrations. Scientia Silvae Sinicae 46, 61, 2010.

31. ZHU W.R., WANG Q.T., LIU M.L., WANG Y.P., ZHANG G.C., LI C.R. Interactive effects of phenolic acid and nitrogen on morphological traits of poplar (Populus $\times$ euramericana 'Neva') fine roots. Chinese Journal of Plant Ecology 39, 1198, 2015.

32. CHUN L., MI G.H., LI J.S., CHEN F.J., ZHANG F.S. Genetic analysis of maize root characteristics in response to low nitrogen stress. Plant and Soil 276, 369, 2005.

33. KING J.S., THOMAS R.B., STRAIN B.R. Morphology and tissue quality of seedling root systems of Pinus taeda and Pinus ponderosa as affected by varying $\mathrm{CO}_{2}$, temperature, and nitrogen. Plant and Soil 195, 107, 1997.

34. STITT M., FEIL R. Lateral root frequency decreases when nitrate accumulates in tobacco transformants with low nitrate reductase activity: consequences for the regulation of biomass partitioning between shoots and root. Plant and Soil 215, 143, 1999.

35. WANG Y.M., CAI H.J., WANG J. The influence of intercropping of wheat and pepper on photosynthetically active radiation and soil temperature. China Rural Water \& Hydropower 1, 14, 2010.

36. GAN Y., BERNREITER A., FILLEUR S., ABRAM B., FORDE B.G. Overexpressing the anrl mads-box gene in transgenic plants provides new insights into its role in the nitrate regulation of root development. Plant \& Cell Physiology 53 (6), 1003, 2012.

37. ONDZIGHI-ASSOUME C.A., CHAKRABORTY S., HARRIS J.M. Environmental nitrate stimulates abscisic acid accumulation in arabidopsis root tips by releasing it from inactive stores. Plant Cell 28 (3), 729, 2016.

38. HU T.Z., CHEN G., HU Z.L. The morphological responses of the root system to the nitrogen stress. Acta Ecology Sinica 30: 205-211, 2010.

39. WANG Y., RIES A., WU K., YANG A., CRAWFORD N.M. The Arabidopsis prohibitin gene phb3 functions in nitric oxide-mediated responses and in hydrogen peroxide-induced nitric oxide accumulation. Plant Cell 22, 249, 2010.

40. WANG Y.Y., CHENG Y.H., CHEN K.E., TSAY Y.F. Nitrate transport, signaling, and use efficiency. Annual Review of Plant Biology 69 (1), 2018.

41. COLLA G., KIM H.J., KYRIACOU M.C., ROUPHAEL Y. Nitrate in fruits and vegetables. Scientia Horticulturae 237, 221, 2018.

42. VICENTE R., PEREZ P., MARTINEZ-CARRASCO R., MORCUENDE R. Improved responses to elevated $\mathrm{CO}_{2}$ in durum wheat at a low nitrate supply associated with the upregulation of photosynthetic genes and the activation of nitrate assimilation. Plant Science 260, 1198, 2017.
43. KONSTANTOPOULOU E., KAPOTIS G., SALACHAS G., PETROPOULOS S.A., KARAPANOS I.C., PASSAM H.C. Nutritional quality of greenhouse lettuce at harvest and after storage in relation to an application and cultivation season. Scientia Horticulturae 125 (2), 93.e1, 2010.

44. ANDREWS M., RAVEN J.A., LEA P.J. Do plants need nitrate? the mechanisms by which nitrogen form affects plants. Annals of Applied Biology 163 (2), 174, 2013.

45. RICHARDSON A.D., BERLYN G.P., GREGOIRE T.G. Spectral reflectance of Picea Rubens (Pinaceae) and Abies balsamea (Pinaceae) Needles along an elevational gradient, Mt. Moosilauke, New Hampshire, USA. American Journal of Botany 88, 667, 2001.

46. CHIKOV V.I., ABDRAKHIMOV F.A., BATASHEVA S.N., KHAMIDULLINA L.A. Characteristics of photosynthesis in maize leaves (C4, plants) upon changes in the level of illuminance and nitrate nutrition. Russian Journal of Plant Physiology 63 (5), 620, 2016.

47. BARHOUMI Z., DJEBALI W.A., CHAIBI W., ABDELLY C., SMAOUI A. Salt impact on photosynthesis and leaf ultrastructure of Aeluropus littoralis. Journal of Plant Research 120, 529, 2007.

48. LI L.F. Comparative study on photosynthetic characteristics of hydrophytes in constructed wetland. Acta Botanica Boreali-Occidentalia Sinica 28, 2094, 2008.

49. PENG T., YAO G., GAO H. Y., LI P.M., WANG W.W., SUN S., ZHAO S.J. Relationship between xanthophyll cycle and photochemical reflectance index measured at leaf or canopy level in two field-grown plant species. Acta Ecologica Sinaca 29, 1987, 2009.

50. DECHANT B., CUNTZ M., VOHLANG M., SCHULZ E., DOKTOR D. Estimation of photosynthesis traits from leaf reflectance spectra: correlation to nitrogen content as the dominant mechanism. Remote Sensing of Environment 196, 279, 2017.

51. YI S.L., LI D., HE S.L., ZHENG Y.Q., MAO S.S. A spectrum based models for monitoring leaf potassium content of Citrus sinensis (L) cv. Jincheng Orange. Scientia Agricultura Sinica 43, 780, 2010.

52. LOHR D., TILLMANN P., ZERCHE S., DRUEGE U., RATH T., MEINKEN E. Non-destructive measurement of nitrogen status of leafy ornamental cuttings by near infrared reflectance spectroscopy (NIRS) for assessment of rooting capacity. Biosystems Engineering 148, 157, 2016.

53. 53. NEYRA C. A., HAGEMAN R. H. Nitrate uptake and induction of nitrate reductase in excised corn roots. Plant Physiology 56: 692-695, 1975.

54. YANG F., WANG X., WEI M., SU X., YAN T. Effects of $\mathrm{NO}_{3}$ - stress and recovery on chlorophyll fluorescence parameters and Atpase activities of cucumber seedling leaves. Chinses Journal of Applied Ecology 17, 403, 2006. 